\title{
RESENHAS
}

\section{O ESPETÁCULO dAS RAÇAS}

\author{
Alessandra El Far
Lilia Katri Moritz Schwarcz: O Espetáculo das Raças: Cientistas, Instituições e Questão Racial no Brasil 1870-1930. São Paulo, Cia. das Letras, 1993.

Os viajantes naturalistas que passaram pelo Brasil no século XIX nunca deixaram de relatar suas impressð̃es sobre a intensa miscigenação de raças aqui existente. Gastavam páginas e páginas tentanto ilustrar esse "festival de cores" caracteristico do pais.

Porém, é a partir da segunda metade do século passado que a questão da raça começa, com maior frequência, a vigorar entre nossos intelectuais. Com as últimas etapas da escravidão, esse grupo de letrados passa a indagar sobre as causas das desigualdades e diferenças entre os homens.

Percebendo os inúmeros debates e acirradas discussões em torno da mistura de raças no Brasil, Lilia Schwarcz descreve, em $\mathrm{O}$ Espetáculo das Raças, o modo pelo qual esses intelectuais enfrentavam o assunto no interior das principais instituições cientificas. Deixa de lado as apressadas conclusões que classificam a produção científica do período como "cópias desautorizadas" das teorias raciais vindas da Europa, para entrar nas suas singularidades e especificidades.

Usando as publicações das faculdades de direito e medicina, dos museus etnográficos e dos institutos históricos e geográficos como material básico de pesquisa, a autora se propõe a fazer uma história social dessas idéias. Recupera os conceitos e modelos, tendo sempre em vista o contexto no qual se inseriram $\mathrm{e}$ os significados que foram adquirindo.

Segue a trajetória dos chamados "homens de sciencia", que, segundo a análise da autora, recortavam e costuravam o evolucionismo e o darwinismo social, cada um a sua maneira, com o objetivo de construir um modelo que conseguisse explicar aqui as diferenças de raça.

Invadidos pelo ideário de 1870 , os intelectuais aos poucos se congregavam nos diversos institutos de pesquisa e, dedicando-se aos estudos desta sociedade, iam dando os primeiros passos das ciências sociais no Brasil. Assumiam a responsabilidade de solucionar os problemas mais imediatos da Nação, tal como a mistura de raças.
Depois de elucidar em que panorama histórico e social emerge essa "classe ilustrada" nacional de finais do século XIX e com ela os vínculos às instituições cientificas, Lilia Schwarcz focaliza as doutrinas raciais européias mais pronunciadas pelos cientistas brasileiros. E explicando as máximas do evolucionismo e do darwinismo social juntamente com os autores europeus que utilizavam os modelos: Gobineau, Le Bon, Taine, dentre outros, parte para os usos e desusos destas correntes nos estabelecimentos nacionais.

Nos museus etnográficos, "lares institucionais de uma antropologia nascente", os cientistas tinham o evolucionismo como principal referência e a partir dele realizavam um intenso trabalho de coleta e classificação de dados. Eram pautados pelo profissionalismo e pela intenção de consolidar o conhecimento científico sobre o homem brasileiro à altura dos círculos intelectuais estrangeiros. Nas palavras da autora: "Partindo da flora $\mathrm{e}$ da fauna para chegar ao homem, ao recolher e analisar, classificar e expor, os museus pretenderam trazer um pouco de ciência e ordem a esse meio tão carente de produções intelectuais dessa categoria." (Schwarcz, 1993:p.91).

Mesmo predominando os padrões biológicos e evolucionistas como instrumentos eficazes para melhor compreender a degeneração racial, os museus na prática "desmentiam qualquer similaridade". Enquanto o Museu Nacional - ligado à figura do Imperador oferecia um projeto associado ao Estado Nacional, o Museu Paulista personificava a figura do "gabinete de quinquilharias" que representasse a elite paulista, e o Museu Paraense Emilio Goeldi sendo a porta de entrada da floresta, privilegiava os estudos da natureza amazônica ao mesmo tempo que consagrava os grupos locais.

No entanto, a responsabilidade de construir uma história oficial cabia aos institutos históricos e geográficos do Rio de Janeiro, São Paulo e Pernambuco. Apesar de atrelados às versões locais, que garantiam suas particularidades, tinham essas 
instituiçס̃es a tarefa comum de reconstruir o passado nacional, pondo em ordem os fatos históricos que até agora se apresentavam dispersos. Assim, os "guardiões da história oficial" cortavam e remotavam as doutrinas raciais escrevendo a história a partir das três raças que, conforme dizia Von Martius, viviam em equilíbrio respeitando as hierarquias e desigualdades biológicas. Nenhum deles guardava uma coerência teórica absoluta. Assegurando as singularidades de cada um, misturavam essas doutrinas justificando a superioridade branca pelo evolucionismo, o natural branqueamento pelo darwinismo socio-biológico e o determinismo para condenar a miscigenação, reservando ao futuro do Brasil, portanto, uma história branca e européia.

Nas faculdades de direito de Recife e São Paulo a preocupação era elaborar um código único nacional que refletisse um Brasil independente dos moldes coloniais. Se por um lado a faculdade de Recife aliava o estatuto científico do direito à biologia evolutiva e à antropologia física e determinista, por outro os juristas paulistas, vendo com maior cautela o modelo determinista, assumiam a postura do liberalismo político. Seguindo suas explicaç̃es, ambas as faculdades anunciavam uma saída viável ao país. Seja por uma nação mestiça uniformizada evocada por Recife, ou por intermédio de um Estado moderno, seguindo a oratória da academia paulista.

E por fim, Lilia Schwarcz chega às faculdades de medicina. Cirurgiões deste país doente, os pupilos da faculdade do Rio de Janeiro se especializavam nas descobertas das doenças tropicais, diferente dos médicos da Bahia, que se incomodavam frente às polêmicas do cruzamento racial. "Ou seja, enquanto para os médicos cariocas tratava-se de combater doenças, para os profissionais baianos era o doente, a população doente que estava em questão." (Schwarcz, 1993:p.190).

Mesmo estando, como vimos, os museus e institutos históricos em meio às reflexões da desigualdades entre os homens, teria sido, na visão da autora, nas faculdades de direito e medicina a maior produção sobre o tema. Os bacharéis do direito, através da lei, acabavam pronunciando os caminhos que o país deveria tomar, e os médicos prescrevendo diagnósticos, receitavam projetos higienistas e saneadores para curar os males da miscigenação.

A preocupação que está presente em todo o livro é a de mostrar as diversas maneiras pelas quais as teorias raciais foram apropriadas no interior de cada uma dessas instituições. E com isso, Lilia Schwarcz aponta a importância de analisar os novos significados conferidos a esses modelos vindos da Europa em relação a situação social, cultural e politica brasileira. Trabalha com a idéia da adoção das teorias não como um caráter inautêntico, e sim como uma redefiniçăo da matriz original.

Lança o desafio de pensar, por exemplo, por que o evolucionismo abandona a noção inicial, onde a sociedade teria por fim o progresso, e aparece nesses locais ligado ao darwinismo social negando a possibilidade da civilização a uma nação negra e mestiça. Ou então, por que o conceito de perfectibilidade, que no século XVIII anunciava terem todos os homens a capacidade de estar sempre se superando, surge aqui como um atributo de poucos.

Afastando o encargo do "caráter postiço", para usar termo de Roberto Schwarz citado pela autora, e o fardo carregado por grande parte dos intelectuais desde o século XIX de que seria preferivel "compor dez trabalhos originais a uma só cópia"l - recebendo a cópia uma posição secundária ao original - , este livro propõe pensar a "originalidade da cópia" e a elasticidade de sua aplicação em contextos tão distintos. Verifica os diferentes sentidos e interpretações que o argumento racial foi recebendo ao passo que os intelectuais íam discutindo os destinos do país e com ele a possibilidade de uma identidade nacional.

Se a raça continua sendo tematizada até hoje, seja em razão dos conflitos sociais e culturais existentes, seja pelas representações populares, é oportuno entrar nas raizes desse debate, que andava nas bocas e nas mentes dos nossos "homens de sciencia", em finais do século XIX.
1. Lsta Trase aparece no romance Quincas Borba, de Machado de $\Lambda$ ssis, quando Rubião, já em seu estado de loucura, pede ao barbeiro um corte de barba igual ao de Napoleão III. E o barbeiro, fazendo seu trabalho, retruca a frase diante da sua impaciência em reproduzir a barba do antigo imperador. In Quincas Borba, de Machado de Assis. S.P. Ed.Núcleo. pg.147. 